\title{
Cognitive Functioning and Psychological Well-being in Breast Cancer Patients on Endocrine Therapy
}

\author{
EDIT BIRO ${ }^{1}$, ZSUZSANNA KAHAN ${ }^{2}$, JANOS KALMAN ${ }^{1}$, ORSOLYA RUSZ ${ }^{2}$, MAGDOLNA PAKASKI ${ }^{1}$, \\ TAMAS IRINYI ${ }^{1}$, GYÖNGYI KELEMEN ${ }^{2}$, RITA DUDÁS ${ }^{2}$, GERGELY DROTOS $^{1}$ and CSABA HAMVAI ${ }^{2}$ \\ ${ }^{1}$ Department of Psychiatry, University of Szeged, Szeged, Hungary; \\ ${ }^{2}$ Department of Oncotherapy, University of Szeged, Szeged, Hungary
}

\begin{abstract}
Background/Aim: Anti-cancer therapies may deteriorate cognitive functioning, affective functioning and psychological well-being. Materials and Methods: In this prospective longitudinal pilot study, premenopausal and postmenopausal patients received adjuvant endocrine therapy (ET) (tamoxifen with or without LHRH analog or aromatase inhibitor) or were observed only (control group). At baseline testing and 6, 12 and 24 months thereafter, cognitive, depression and anxiety tests and quality of life (QOL) measurements were performed. Results: Overall, 46 cases were evaluated. None of the studied cognitive parameters differed between the subgroups or changed by time. No differences were found regarding anxiety, depression or $Q O L$ measures either. Baseline cognitive test and QOL results were in association with later anxiety and depression. Conclusion: No cognitive impairment was found during the two years of ET. Baseline cognitive scores and QOL dimensions proved good predictors of later anxiety and depression.
\end{abstract}

Breast cancer (BC) patients represent the largest group among long-surviving cancer-affected populations (1). Adjuvant curative therapies are applied in the majority of cases that possibly influence their cognitive functioning and psychological well-being (2-5). The adverse effects of adjuvant therapies on cognitive functioning including verbal memory (immediate and delayed recall), visuo-spatial memory, executive functioning, attention/concentration, psychomotor speed, verbal fluency, verbal articulation

This article is freely accessible online.

Correspondence to: Zsuzsanna Kahán, MD, D.Sc. Habil, Professor and Head of the Department of Oncotherapy, University of Szeged, Korányi fasor 12, H-6720 Szeged, Hungary. Tel: +36 62545404, Fax: +36 62545922, e-mail: kahan.zsuzsanna@med.u-szeged.hu

Key Words: Anxiety, breast cancer, cognitive function, depression, endocrine therapy, QOL. (language skills) may exert profound effects on quality of life (QOL) (6-8). Chemotherapy-related cognitive deterioration originally named as "chemobrain" is a wellknown phenomenon which includes various chemotherapyinduced deficits and impairments such as decline of verbal memory and psychomotor functioning (3, 9-11). Similar consequences of endocrine therapy (ET) have been less intensively investigated. Some data suggest that these longterm therapies cause significant cognitive deficits as compared to surgery-only or healthy control cases $(5,12-14)$, while other studies show only minor $(15,16)$ or no such effects (17). Since endocrine therapy varies according to age and risk status, it is even more difficult to distinquish between the effects of the various treatment regimens including tamoxifen or the aromatase inhibitors with or without GnRH analogs $(15,18,19)$.

The mechanism of cancer therapy-associated cognitive changes is complex, including the impact of surgery and medical therapies and the overwhelming psychological effects of the diagnosis and therapy (4). Regarding the effects of chemotherapy, not only neurotoxicity, but also related endocrine effects may be present. The pure effect of a specific therapy is difficult to investigate, and needs a large number of patients. The impact of adjuvant chemotherapy or endocrine therapy on QOL, depression and anxiety was studied in the UK START Trial in a large group of 2208 patients at the start of radiotherapy; only chemotherapy and younger age were predictors of poorer QOL (8). A systematic review and metaanalysis of 14 studies demonstrated that ET significantly alters various cognitive domains both in the short and long terms, and that tamoxifen impairs cognitive functioning to a lesser extent than aromatase inhibitors do $(5,15)$. Estrogen receptors found in many areas of the brain (hippocampus, prefrontal cortex and amygdala) are considered important in cognition, and play a role in performing tasks requiring executive function, verbal learning, and memory. Estrogen is needed for tissue integrity. Evidence derived from basic and clinical research indicates that estradiol stimulates neuroplasticity and improves cognitive performance $(4,20-22)$. The blockade of 
estrogen action deprives the brain from modulation via estradiol resulting in decreased neuroplasticity and impaired cognitive functioning (21).

The understanding of previous findings on cognitive functioning after ET is complicated by the use of different methods (neuropsychological batteries, definitions of cognitive impairment or longitudinal decline, the involvement of $\mathrm{BC}$ or healthy controls), the confounding effects of various cancer treatments, the varying times of menopause, the patients' psychological status and treatment compliance and, many times small sample sizes $(4,5)$. Limited experience is gained on old patients $(2,16,23,24)$. Gaining knowledge on cancer therapy-induced cognitive impairment would yield practical implications. First, all possible adverse consequences including cognitive deficits must be carefully balanced against benefits at treatment decision. Second, if ET leads to significant cognitive impairment, adherence to medication may be easily compromised. Third, specific supportive treatments (training strategies) should be used if such effects of therapy are identified $(25,26)$.

The primary aim of this pilot prospective observational study was to analyze the effects of ET on cognitive functioning in premenopausal and postmenopausal BC patients who had not received chemotherapy as part of their treatment. We also intended to investigate the depression and anxiety symptoms as well as the QOL aspects along the assessment time.

\section{Patients and Methods}

All participants provided written informed consent, and none received financial or material compensation. The present study was executed in agreement with the Declaration of Helsinki and was approved by the local Ethics Committee (approval number: SZTEREB 15/2009).

Eligible patients were Hungarian premenopausal and postmenopausal breast cancer patients between the ages of 20-90 years. The only inclusion criterion was curative surgery for estrogen and/or progesterone receptor positive breast carcinoma. The exclusion criteria included the need of adjuvant chemotherapy, the presence of psychiatric/mental disorder, history of stroke, Parkinson's disease, alcohol or drug abuse. The administration or avoidance of adjuvant ET was based on the consideration of the tumor prognostic factors and patient-related features in accordance with the institutional and international guidelines. Those patients who received ET including $20 \mathrm{mg}$ tamoxifen with or without LHRH analog (leuprolide acetate $3.75 \mathrm{mg}$ or goserelin $3.6 \mathrm{mg}$ every 28 days) or an aromatase inhibitor (letrozole $1 \mathrm{mg}$ or anastrozole 2.5 $\mathrm{mg}$ ), were compared with patients without any adjuvant ET. According to the type of ET, two groups were created: 1. tamoxifenbased group (TAM) including those patients who received tamoxifen with or without LHRH analog, and 2. the aromatase inhibitor group (AI). The control group (C) did not receive ET.

In this prospective longitudinal study, the findings of the first two years of treatment in the patients who remained adherent to the assigned protocol were analyzed. The schedule of assessments is indicated in Figure 1. Briefly, the initial assessment (T1) was
Table I. Patient- and tumor-related characteristics of the study population.

\begin{tabular}{|c|c|c|c|c|}
\hline Parameter & $\begin{array}{c}\text { TAM } \\
(\mathrm{n}=14)\end{array}$ & $\begin{array}{c}\mathrm{AI} \\
(\mathrm{n}=18)\end{array}$ & $\begin{array}{c}\mathrm{C} \\
(\mathrm{n}=14)\end{array}$ & $p$-Value* \\
\hline Mean age, years & 53.6 & 63.3 & 56.9 & 0.01 \\
\hline $\mathrm{SD}$ & 11.2 & 5.5 & 8.6 & \\
\hline Range & $31-74$ & $51-71$ & $40-69$ & \\
\hline Years of education & 13.3 & 12.3 & 14.1 & 0.41 \\
\hline $\mathrm{SD}$ & 4.5 & 3.2 & 3.6 & \\
\hline Range & $5-22$ & $8-18$ & $8-20$ & \\
\hline Menostatus & & & & 0.01 \\
\hline Premenopausal & $8(57 \%)$ & - & $4(29 \%)$ & \\
\hline Postmenopausal & $6(43 \%)$ & $18(100 \%)$ & $10(71 \%)$ & \\
\hline Underwent radiotherapy & $12(86 \%)$ & $13(72 \%)$ & $12(86 \%)$ & 0.33 \\
\hline \multicolumn{5}{|c|}{ Primary tumor } \\
\hline pTis & $2(14 \%)$ & - & - & 0.13 \\
\hline pT1 & $8(57 \%)$ & $11(61 \%)$ & $13(93 \%)$ & \\
\hline pT2 & $4(29 \%)$ & $6(33 \%)$ & $1(7 \%)$ & \\
\hline pT3 & - & $1(6 \%)$ & - & \\
\hline \multicolumn{5}{|l|}{ Nodal status } \\
\hline pNo & $8(57 \%)$ & $13(72 \%)$ & $14(100 \%)$ & 0.08 \\
\hline $\mathrm{pN} 1$ & $5(36 \%)$ & $4(22 \%)$ & - & \\
\hline $\mathrm{pN} 2$ & - & - & - & \\
\hline pN3 & $1(7 \%)$ & $1(6 \%)$ & - & \\
\hline \multicolumn{5}{|l|}{ Histology } \\
\hline IDC & $12(86 \%)$ & $11(61 \%)$ & $11(79 \%)$ & 0.58 \\
\hline ILC & - & $4(22 \%)$ & $1(7 \%)$ & \\
\hline Other & $2(14 \%)$ & $3(17 \%)$ & $2(14 \%)$ & \\
\hline \multicolumn{5}{|l|}{ Histological grade } \\
\hline 0 & $2(14 \%)$ & - & - & \\
\hline 1 & $4(29 \%)$ & $3(17 \%)$ & $7(50 \%)$ & \\
\hline 2 & $8(57 \%)$ & $13(72 \%)$ & $4(29 \%)$ & 0.13 \\
\hline 3 & - & $2(11 \%)$ & $3(21 \%)$ & \\
\hline
\end{tabular}

SD: Standard deviation. ${ }^{*} p$-values for analysis of variance.

performed after the definitive breast surgery prior to the enrolment into the study. Follow-up assessments were conducted 6 months (T2), 12 months (T3) and 24 months (T4) thereafter.

Neuropsychological assessment. All the assessments were performed by skilled psychologists and psychiatrists under standardized circumstances, in the morning. The following neuropsychological tests designed to investigate cognitive capacity, anxiety, depression and QOL were used.

Cognitive tests. The Alzheimer' Disease Assessment Scale (ADAS) $(27,28)$ was designed to measure the severity of the most important cognitive symptoms of Alzheimer's disease. Its cognitive subscale (ADAS-Cog) consists of 11 tasks measuring the disturbances of memory, language, praxis, attention and other cognitive abilities. Higher total scores indicate more severe cognitive impairments.

The Cambridge Neuropsychological Testing Automated Battery (CANTAB) (29) contains touchscreen neuropsychological tests of cognition, specifically designed to assess central nervous system disorders and cognitive function across a range of domains. From 


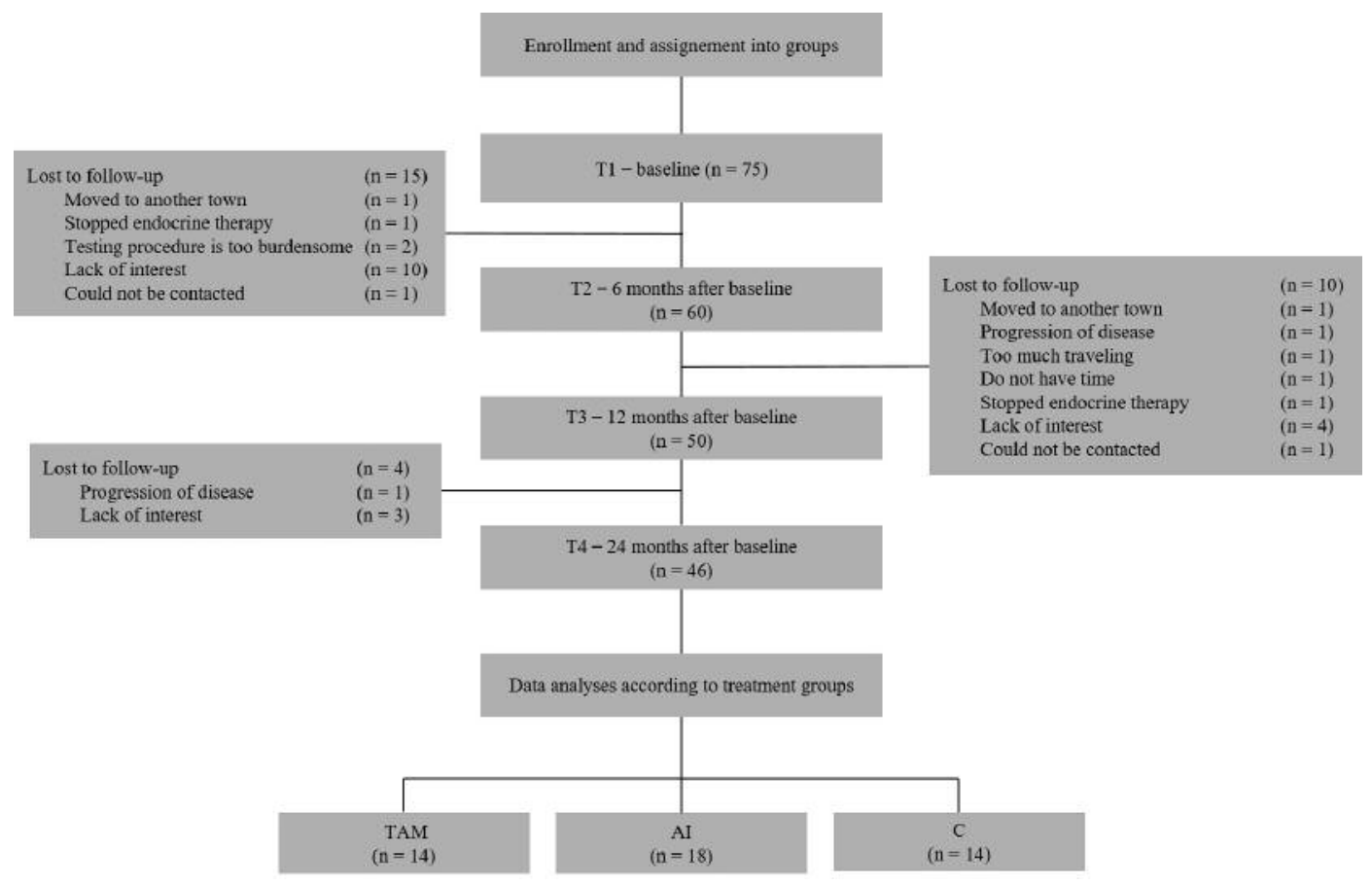

Figure 1. Consort diagram of the study.

this battery we chose the Paired Associates Learning (PAL) test which assesses visual memory and new learning. It has three main indicators: stages completed (PAL1), stages completed on first trial (PAL2) and first trial memory score (PAL3).

The Clock-Drawing Test (CDT) $(30,31)$ is used for screening cognitive impairment and dementia and a measure of spatial dysfunction and neglect. The test requires verbal understanding, memory and spatially coded knowledge in addition to constructive skills. Maximal total score is 10 , lower score indicates cognitive impairment.

The Mini-Mental State Examination (MMSE) $(32,33)$ is the most commonly used test for basic cognitive skills such as orientation in time and space, memory, attention and language. Lower total scores indicate more severe dementia.

Depression and anxiety tests. The Beck Depression Inventory (BDI) (34) is one of the most widely used self-administered psychometric tests for measuring the severity of depression. It contains 21 questions; each answer being scored on a scale value of 0-3. Higher total scores indicate more severe depressive symptoms.

The Hamilton Depression Rating Scale (HDRS) $(35,36)$ is a multiple-item questionnaire scored and administered by qualified raters, used to evaluate the severity of depression by probing mood, feelings of guilt, suicide ideation, insomnia, agitation or retardation, anxiety, weight loss and somatic symptoms. It contains 17 items pertaining to symptoms of depression experienced over the past week.

The Spielberger State-Trait Anxiety Inventory (STAI-S, STAI-T) $(37,38)$ is a self-administered anxiety questionnaire. The STAI-S measures an individual's emotional response to an actual stressful situation. The STAI-T measures an individual's predisposition to anxiety determined by his/her personality and estimates how a person generally feels. It consists of 20 items each rated 1-4. A higher score indicates greater anxiety.

QOL questionnaire. The Functional Assessment of Cancer TherapyBreast cancer (FACT-B) (39) was used to measure multidimensional QOL. It contains 42 statements; patients select their response on a scale of 0-4. With this questionnaire, 5 dimensions may be assessed: physical well-being (PWB), social/family well-being (SWB), emotional well-being (EWB), functional well-being (FWB) and breast cancer subscale (BCS).

The tests were administered in the same order to all patients: BDI, MMSE, ADAS-Cog, CDT, PAL, HDRS, STAI-S, STAI-T and FACT-B. It took approximately $1 \mathrm{~h}$ to complete the tests for every participant.

Statistical analysis. IBM SPSS Statistics for Windows version 20.0 was used for all analyses. A $p<0.05$ was considered as statistically significant.

Changes from $\mathrm{T} 1$ to $\mathrm{T} 4$ and between groups were analyzed by using repeated measures of ANOVA in which the cognitive test (ADAS-Cog, CDT, MMSE, PAL subscales: PAL1, PAL2, PAL3) scores were within-subject factors, and the treatment type was the between-subject factor. In this model the follow up time (T1-T4) was the main factor. We chose this method for its demonstrated power and capability to compare the three groups and account for the four assessment times. The same method was used in the cases of mood questionnaire (BDI, HDRS, STAI- S, STAI-T) scores and the FACT-B questionnaire (PWS, SWB, EWB, FWB, BCS) subscales as within-subject factors. 
Table II. Comparison of cognitive, affective an QOL parameters in the different treatment and control groups during the T1-T4 time intervals.

\begin{tabular}{|c|c|c|c|c|c|c|c|c|c|}
\hline \multirow[t]{2}{*}{ Parameter } & \multicolumn{2}{|c|}{$\begin{array}{c}\text { TAM } \\
(\mathrm{n}=13)\end{array}$} & \multicolumn{2}{|c|}{$\begin{array}{c}\mathrm{AI} \\
(\mathrm{n}=17)\end{array}$} & \multicolumn{2}{|c|}{$\begin{array}{c}C \\
(n=15)\end{array}$} & \multirow[t]{2}{*}{$\mathrm{F}$} & \multirow[t]{2}{*}{$p$-Value* } & \multirow[t]{2}{*}{$\eta^{2}$} \\
\hline & M & SD & M & SD & M & SD & & & \\
\hline \multicolumn{10}{|c|}{ Cognitive tests } \\
\hline \multicolumn{10}{|c|}{ ADAS-Cog } \\
\hline $\mathrm{T} 1$ & 6 & 3.6 & 8 & 2.6 & 6 & 2.2 & 1.44 & 0.207 & 0.09 \\
\hline $\mathrm{T} 2$ & 5 & 2.4 & 7 & 3.1 & 5 & 2.1 & & & \\
\hline $\mathrm{T} 3$ & 6 & 3.4 & 6 & 2.3 & 5 & 2.5 & & & \\
\hline $\mathrm{T} 4$ & 7 & 3.8 & 6 & 2.3 & 5 & 2.4 & & & \\
\hline \multicolumn{10}{|l|}{ CDT } \\
\hline $\mathrm{T} 1$ & 9 & 1.5 & 9 & 1.8 & 9 & 1.2 & 0.78 & 0.549 & 0.04 \\
\hline $\mathrm{T} 2$ & 9 & 1.8 & 9 & 1.1 & 10 & 0.4 & & & \\
\hline $\mathrm{T} 3$ & 9 & 1.9 & 10 & 0.8 & 10 & 0.3 & & & \\
\hline $\mathrm{T} 4$ & 9 & 2.7 & 9 & 2.8 & 10 & 0.3 & & & \\
\hline \multicolumn{10}{|l|}{ MMSE } \\
\hline $\mathrm{T} 1$ & 29 & 1.2 & 28 & 3.0 & 29 & 0.7 & 0.37 & 0.817 & 0.04 \\
\hline $\mathrm{T} 2$ & 29 & 1.2 & 29 & 1.0 & 30 & 0.7 & & & \\
\hline $\mathrm{T} 3$ & 29 & 0.8 & 29 & 1.4 & 29 & 1.1 & & & \\
\hline $\mathrm{T} 4$ & 29 & 1.3 & 29 & 0.8 & 29 & 1.2 & & & \\
\hline \multicolumn{10}{|l|}{ PAL 1} \\
\hline $\mathrm{T} 1$ & 7 & 0.7 & 6 & 0.7 & 7 & 0.6 & 0.70 & 0.647 & 0.04 \\
\hline $\mathrm{T} 2$ & 7 & 1.1 & 7 & 0.6 & 7 & 0.5 & & & \\
\hline $\mathrm{T} 3$ & 7 & 0.8 & 7 & 0.9 & 7 & 0.5 & & & \\
\hline $\mathrm{T} 4$ & 7 & 0.9 & 7 & 0.7 & 7 & 0.8 & & & \\
\hline \multicolumn{10}{|l|}{ PAL 2} \\
\hline $\mathrm{T} 1$ & 5 & 0.7 & 5 & 1.3 & 6 & 0.5 & 1.78 & 0.108 & 0.07 \\
\hline $\mathrm{T} 2$ & 6 & 0.9 & 6 & 1.0 & 6 & 0.9 & & & \\
\hline $\mathrm{T} 3$ & 6 & 0.7 & 5 & 1.1 & 6 & 0.7 & & & \\
\hline $\mathrm{T} 4$ & 6 & 0.6 & 5 & 0.9 & 6 & 0.7 & & & \\
\hline \multicolumn{10}{|l|}{ PAL 3} \\
\hline $\mathrm{T} 1$ & 15 & 3.0 & 12 & 5.1 & 16 & 2.9 & 1.44 & 0.226 & 0.05 \\
\hline $\mathrm{T} 2$ & 15 & 4.3 & 14 & 4.3 & 17 & 2.5 & & & \\
\hline $\mathrm{T} 3$ & 20 & 9.9 & 15 & 4.5 & 18 & 1.3 & & & \\
\hline $\mathrm{T} 4$ & 16 & 3.2 & 14 & 3.4 & 17 & 2.9 & & & \\
\hline Depression & & & & & & & & & \\
\hline BDI & & & & & & & & & \\
\hline $\mathrm{T} 1$ & 7 & 3.6 & 10 & 7.4 & 7 & 6.2 & 0.71 & 0.619 & 0.04 \\
\hline $\mathrm{T} 2$ & 7 & 8.8 & 10 & 8.2 & 7 & 7.4 & & & \\
\hline $\mathrm{T} 3$ & 6 & 3.9 & 8 & 7.8 & 6 & 5.5 & & & \\
\hline $\mathrm{T} 4$ & 7 & 5.9 & 7 & 7.3 & 5 & 4.4 & & & \\
\hline HDRS & & & & & & & & & \\
\hline $\mathrm{T} 1$ & 3 & 2.6 & 5 & 4.8 & 4 & 5.3 & 0.23 & 0.965 & 0.01 \\
\hline $\mathrm{T} 2$ & 3 & 3.8 & 5 & 5.4 & 3 & 4.7 & & & \\
\hline $\mathrm{T} 3$ & 3 & 4.1 & 6 & 6.7 & 2 & 3.2 & & & \\
\hline $\mathrm{T} 4$ & 2 & 2.6 & 5 & 6.3 & 3 & 2.4 & & & \\
\hline STAI-S & & & & & & & & & \\
\hline $\mathrm{T} 1$ & 40 & 10.5 & 44 & 16.7 & 40 & 9.7 & 0.842 & 0.519 & 0.04 \\
\hline $\mathrm{T} 2$ & 41 & 14.8 & 39 & 13.7 & 40 & 12.7 & & & \\
\hline $\mathrm{T} 3$ & 36 & 9.5 & 39 & 12.9 & 35 & 12.3 & & & \\
\hline $\mathrm{T} 4$ & 39 & 11.6 & 41 & 14.6 & 33 & 6.6 & & & \\
\hline STAI-T & & & & & & & & & \\
\hline $\mathrm{T} 1$ & 43 & 7.4 & 44 & 9.9 & 44 & 9.2 & 1.70 & 0.135 & 0.07 \\
\hline $\mathrm{T} 2$ & 41 & 11.5 & 42 & 13.1 & 42 & 10.9 & & & \\
\hline $\mathrm{T} 3$ & 42 & 10.7 & 42 & 11.5 & 37 & 11.0 & & & \\
\hline $\mathrm{T} 4$ & 41 & 10.7 & 44 & 13.3 & 38 & 8.8 & & & \\
\hline QOL quest & & & & & & & & & \\
\hline PWB & & & & & & & & & \\
\hline $\mathrm{T} 1$ & 25 & 3.0 & 22 & 6.4 & 23 & 4.1 & 0.65 & 0.694 & 0.03 \\
\hline $\mathrm{T} 2$ & 24 & 4.1 & 23 & 6.0 & 23 & 4.9 & & & \\
\hline $\mathrm{T} 3$ & 25 & 3.9 & 23 & 5.0 & 25 & 4.4 & & & \\
\hline $\mathrm{T} 4$ & 25 & 3.0 & 22 & 6.0 & 25 & 3.7 & & & \\
\hline
\end{tabular}


Table II. Continued

\begin{tabular}{|c|c|c|c|c|c|c|c|c|c|}
\hline \multirow[t]{2}{*}{ Parameter } & \multicolumn{2}{|c|}{$\begin{array}{c}\text { TAM } \\
(n=13)\end{array}$} & \multicolumn{2}{|c|}{$\begin{array}{c}\mathrm{AI} \\
(\mathrm{n}=17)\end{array}$} & \multicolumn{2}{|c|}{$\begin{array}{c}C \\
(n=15)\end{array}$} & \multirow[t]{2}{*}{ F } & \multirow[t]{2}{*}{$p$-Value* } & \multirow[t]{2}{*}{$\eta^{2}$} \\
\hline & M & SD & M & SD & M & SD & & & \\
\hline \multicolumn{10}{|l|}{ SWB } \\
\hline $\mathrm{T} 1$ & 22 & 4.7 & 22 & 5.6 & 24 & 3.9 & \multirow[t]{4}{*}{0.96} & \multirow[t]{4}{*}{0.444} & \multirow[t]{4}{*}{0.05} \\
\hline $\mathrm{T} 2$ & 21 & 5.1 & 23 & 6.5 & 24 & 3.8 & & & \\
\hline $\mathrm{T} 3$ & 22 & 5.6 & 22 & 5.3 & 24 & 3.6 & & & \\
\hline $\mathrm{T} 4$ & 22 & 4.4 & 22 & 6.1 & 22 & 4.5 & & & \\
\hline \multicolumn{10}{|l|}{ EWB } \\
\hline $\mathrm{T} 1$ & 19 & 2.8 & 19 & 5.2 & 20 & 4.3 & \multirow[t]{4}{*}{0.41} & \multirow[t]{4}{*}{0.869} & \multirow[t]{4}{*}{0.02} \\
\hline $\mathrm{T} 2$ & 20 & 3.1 & 19 & 5.6 & 21 & 3.9 & & & \\
\hline $\mathrm{T} 3$ & 20 & 3.5 & 20 & 2.6 & 22 & 3.0 & & & \\
\hline $\mathrm{T} 4$ & 20 & 2.9 & 20 & 3.7 & 22 & 2.0 & & & \\
\hline \multicolumn{10}{|l|}{ FWB } \\
\hline $\mathrm{T} 1$ & 19 & 5.0 & 19 & 4.3 & 20 & 4.8 & \multirow[t]{4}{*}{0.36} & \multirow[t]{4}{*}{0.906} & \multirow[t]{4}{*}{0.02} \\
\hline $\mathrm{T} 2$ & 19 & 5.5 & 18 & 6.9 & 21 & 4.6 & & & \\
\hline $\mathrm{T} 3$ & 20 & 5.1 & 17 & 6.9 & 21 & 5.0 & & & \\
\hline $\mathrm{T} 4$ & 21 & 4.7 & 20 & 6.1 & 21 & 4.0 & & & \\
\hline \multicolumn{10}{|l|}{ BCS } \\
\hline $\mathrm{T} 1$ & 31 & 5.2 & 27 & 6.6 & 32 & 7.5 & \multirow[t]{4}{*}{0.85} & \multirow[t]{4}{*}{0.47} & \multirow[t]{4}{*}{0.04} \\
\hline $\mathrm{T} 2$ & 28 & 5.0 & 27 & 7.7 & 36 & 23.1 & & & \\
\hline T3 & 32 & 6.8 & 26 & 8.7 & 33 & 6.8 & & & \\
\hline $\mathrm{T} 4$ & 31 & 6.8 & 27 & 9.3 & 32 & 6.8 & & & \\
\hline
\end{tabular}

M: Mean; SD: standard deviation; $\eta^{2}$ : partial eta squared - effect size; MMSE: mini-mental state examination; ADAS-Cog: Alzheimer's disease assessment scale; CDT: Clock-Drawing test; PAL 1: PAL stages completed; PAL 2: PAL stages completed on first trial; PAL 3: PAL first trial memory score; HDRS: Hamilton depression rating scale; BDI: beck depression inventory; STAI-S: state-trait anxiety inventory - State subscale; STAI-T: state-trait anxiety inventory - trait subscale; PWB: physical well-being; SWB: social/family well-being; EWB: emotional well-being; FWB: functional well-being; BCS: breast cancer subscale.

Linear regression analyses with the stepwise method were used to examine the relationship between the cognitive tests, FACT-B subscales and anxiety and depression scales. Independent variables were the cognitive tests (ADAS-Cog, CDT, MMSE, PAL subscales: PAL1, PAL2, PAL3) and FACT subscales at T1 (PWB, SWB, EWB, FWB, BCS); dependent variables were the BDI, HDRS and STAI$\mathrm{S}, \mathrm{STAI}-\mathrm{T}$ scores at $\mathrm{T} 4$.

\section{Results}

Descriptive statistics. Although 75 patients were enrolled, due to the withdrawal of some participants for various reasons (disease progression, non-compliance to therapy, withdrawal of consent) at different assessment times, the analyses were based on the data of 46 patients who attended to and completed all of the four visits (T1-T4) (Figure 1). At the final analysis, the TAM group consisted of 14 participants, the AI group of 18 patients and the $\mathrm{C}$ group of 14 participants. The groups showed similar educational level, but differed by age and menopausal status $(p=0.01)$. Patients in the control group had obviously lower stage cancers. Overall, $37(80 \%)$ of the patients received radiotherapy (Table I).
Neuropsychological performance. All the analyses were performed with repeated measures of ANOVA with the age variable as a covariate. This way significant age differences could be controlled. None of the studied parameters showed significant changes by time in the overall population or within the study groups.

First, the mean scores of the cognitive tests were compared between the study groups. Only slight difference was detected when all the test data were analyzed $(\mathrm{F}(36,46)=1.57, p=0.074$, $\left.\eta^{2}=0.55\right)$. With Bonferroni pairwise comparison, this difference was not confirmed. When the same values were compared according to the tests and time points, no differences were found (Table II). During the two years of observational time, no difference was detected between the groups regarding the mean scores of the depression and anxiety tests, taking into account the time of the test $\left(\mathrm{F}(24,62)=1.35, p=0.172, \eta^{2}=0.34\right)$ (Table II). Likewise, no differences were found in the FACTB subscale mean scores during the analysis between the three groups if the different time points were taken into account $\left(\mathrm{F}(30,52)=0.62, p=0.920, \eta^{2}=0.26\right)$ (Table II).

Next, linear regression models were developed. Various associations were found between the baseline QOL/cognitive 
test results and depression/anxiety scores as measured at the 2-year follow-up visit (T4). The initial cognitive test results were in association with later depression and anxiety. Baseline functional and emotional well-being was associated with later depression and anxiety (Table III). The combined results of baseline MMSE and FWB predicted BDI scores two years later $(30 \%(\mathrm{~F}(2,39)=9.88, p<0.001)$. Likewise, the MMSE test and FWB subscale were significant predictors of STAI-S; the model accounted for $42 \%$ of the variance $(\mathrm{F}(2,39)=16.05, p<0.001)$. Also, STAI-T scores at two years were in association with baseline FWB subscale and MMSE, the model accounted for $37 \%$ of the individual differences $(\mathrm{F}(2,39)=12.79, p<0.001)$. The combined scores of CDT and EWB were able to predict the HDRS score two years after enrolment $(27 \%(\mathrm{~F}(2,38)=8.50, p=0.001)$. No associations were detected between the other parameters such as SWB, BCS, ADAS-Cog and PAL subscales (PAL1, PAL2, PAL3) and the mood questionnaire scores (Table III).

\section{Discussion}

In this pilot prospective study, we detected no negative effect of 2-year ET on cognitive functioning in the overall patient population or any of the treatment groups. An unexpected finding was that baseline cognitive tests and QOL measures were in association with later depression and anxiety, and their combined use could even better predict the patient's long-term psychological performance status. For future studies, we propose the use of more specific cognitive batteries for the consideration of the various cognitive domains, and find worthy to complement the analysis of different cognitive domains with that of affective functioning and QOL.

There are mixed data on the cognitive effects of ET (Table IV). In the recently published prospective longitudinal Mind Body Study, Van Dyk et al. (17) reported on the complex long-term effects of ET on neuropsychological functions (17). The analysis was based on both neuropsychological testing and self-reported data in 189 BC patients among which follow-up was extended to 3-6 years in 102 participants. On the contrary to the perceived hypothesis, no difference was found in any of the neuropsychological domains on the basis of ET use. Across most domains, there was similar improvement in both groups during the years of follow-up. The significance of these results is justified by the large number of patients, long follow-up in more than half of the cases, complex methodology in various domains and careful statistical analysis; the design of the follow-up lowered practice effects (17). Nevertheless, the confounder effects of chemotherapy (about half of the patients in both groups received chemotherapy $<3$ months within entering the study), varying ET and menopausal status were not excluded. Interestingly, the prior reports on the same study suggested that ET leads to adverse cognitive outcomes (12). In a recent metaanalysis, based on a total of 911 BC patients and 911 controls in 14 studies, ET was not associated with any longitudinal effect on cognitive functions, while in crosssectional comparisons, ET patients performed worse on verbal learning/memory (15). Similarly, no changes in cognitive functions were found in 2 longitudinal studies (18, 19). Other trials showed that ET affected neuropsychological functioning overall and verbal learning/memory the most (5, $14,15)$. Limited number of studies focus on the comparison of various endocrine interventions, and their outcome is still ambiguous due to methodological issues $(4,14,15,18,19)$. In a metaanalysis of 14 studies, patients on tamoxifen therapy performed better than patients on a non-steroidal AI, but showed less performance differences relative to steroidal AI-treated patients (15). Le Rhun et al. (19) investigated the effects of adjuvant tamoxifen $v s$. an $\mathrm{AI}$ in a randomized phase III study in 74 postmenopausal BC patients (19). No differences were found in the verbal episodic memory, visual memory, psychomotor speed and executive functions or the patient-reported autonomy, QOL or emotional state measures (19). In the Co-SOFT study, a homogeneous group of 74 premenopausal $\mathrm{BC}$ patients were treated with tamoxifen with or without ovarian suppression or an AI with ovarian suppression (18). The primary end-point was objective cognitive functioning the secondary outcome was patientreported outcome between patients with ovarian ablation $v s$. patients treated with tamoxifen only. After 1 year of ET, no significant changes were detected in the global composite score of the CogState tasks, but patients in the combination endocrine therapy arms reported greater cognitive decline than in the tamoxifen-only arm (18).

Some studies suggest that baseline depression and anxiety predict later cognitive decline. Tometich et al. (24), in a longitudinal study, investigated the effects of baseline anxiety and depression together with fatigue, pain and sleep disturbances on perceived and objective cognitive functions in 319 BC patients and 347 non-cancer controls, all aged $\geq 60$ years. Although all groups showed improvements in neuropsychological scores over time, $16 \%$ of the patients who had high symptoms at baseline had lower perceived and objective cognition at that time point, and lower perceived cognition all along the observation time (24). Lower functional well-being at baseline predicted lower BC-specific QOL at all time points. In the baseline report of the Mind Body Study, prior to the start of ET, neuropsychological performance did not vary based on the use of chemotherapy, radiotherapy, the avoidance or combined use of these but, high symptom status correlated with fatigue, pain and sleep quality (40). Our finding that different indicators of initial cognitive functioning may be determinants of later decline in psychological functioning and QOL, has been an original finding. The initial cognitive test results and emotional wellbeing were in association with later depression and anxiety. 
Table III. Associations between the baseline cognitive and QOL characteristics versus depression and anxiety two years after study entry (linear regression analysis); significant model components are indicated with grey background.

\begin{tabular}{|c|c|c|c|c|c|c|c|c|c|c|c|c|c|c|c|c|}
\hline & \multicolumn{4}{|c|}{ BDI (T4) } & \multicolumn{4}{|c|}{ HDRS (T4) } & \multicolumn{4}{|c|}{ STAI-S (T4) } & \multicolumn{4}{|c|}{ STAI-T (T4) } \\
\hline & $\mathrm{t}$ & $\beta$ & $p$-Value & Partial & $\mathrm{t}$ & $\beta$ & $p$-Value & Partial & $\mathrm{t}$ & $\beta$ & $p$-Value & Partial & $\mathrm{t}$ & $\beta$ & $p$-Value & Partial \\
\hline $\mathrm{T} 1$ & \multicolumn{16}{|c|}{ Cognitive Tests } \\
\hline MMSE & -2.34 & -0.32 & 0.024 & -0.35 & -1.0 & -0.16 & 0.322 & -0.16 & -3.46 & -0.43 & 0.001 & -0.48 & -2.91 & -0.38 & 0.006 & -0.42 \\
\hline ADAS & -0.39 & -0.05 & 0.699 & -0.06 & 0.64 & 0.09 & 0.525 & 0.11 & -0.67 & -0.08 & 0.504 & -0.11 & -0.54 & -0.07 & 0.596 & -0.09 \\
\hline CDT & -1.85 & -0.23 & 0.073 & -0.29 & -2.08 & -0.28 & 0.044 & -0.32 & -1.83 & -0.21 & 0.074 & -0.29 & -0.93 & -0.12 & 0.359 & -0.15 \\
\hline PAL1 & 1.25 & 0.17 & 0.218 & 0.2 & 1.29 & 0.19 & 0.205 & 0.21 & 0.72 & 0.09 & 0.474 & 0.12 & 0.88 & 0.12 & 0.384 & 0.14 \\
\hline PAL2 & 1.54 & 0.20 & 0.132 & 0.24 & 0.78 & 0.11 & 0.442 & 0.13 & -0.77 & -0.09 & 0.449 & -0.12 & 0.26 & 0.03 & 0.798 & 0.04 \\
\hline PAL3 & 1.45 & 0.19 & 0.154 & 0.23 & 1.17 & 0.17 & 0.250 & 0.19 & -0.17 & -0.20 & 0.868 & -0.03 & 0.23 & 0.03 & 0.822 & 0.04 \\
\hline \multicolumn{17}{|c|}{ QOL questionnaire subscales } \\
\hline PWB & -0.56 & -0.08 & 0.580 & -0.09 & -1.86 & -0.27 & 0.072 & -0.29 & -2.00 & -0.26 & 0.053 & -0.31 & -1.85 & -0.25 & 0.072 & -0.29 \\
\hline SWB & -0.10 & -0.02 & 0.919 & -0.02 & -0.18 & -0.03 & 0.860 & -0.03 & 0.46 & 0.06 & 0.647 & 0.08 & 0.10 & 0.01 & 0.923 & 0.02 \\
\hline EWB & 0.13 & 0.02 & 0.899 & 0.02 & -3.76 & -0.51 & 0.001 & -0.52 & -0.26 & -0.05 & 0.796 & -0.04 & -0.19 & -0.03 & 0.851 & -0.03 \\
\hline FWB & -2.87 & -0.39 & 0.007 & -0.42 & -1.16 & -0.2 & 0.255 & -0.19 & -3.2 & -0.40 & 0.003 & -0.46 & -3.04 & -0.40 & 0.004 & -0.44 \\
\hline BCS & -0.06 & -0.01 & 0.950 & -0.01 & 0.002 & $<0.001$ & 0.998 & $<0.001$ & -0.74 & -0.09 & 0.465 & -0.12 & -0.74 & -0.10 & 0.465 & -0.12 \\
\hline
\end{tabular}

MMSE: Mini-mental state examination; ADAS-Cog: Alzheimer's disease assessment scale; CDT: Clock-Drawing test; PAL 1: PAL stages completed; PAL 2: PAL stages completed on first trial; PAL 3: PAL first trial memory score; HDRS: Hamilton depression rating scale; BDI: Beck depression inventory; STAI-S: state-trait anxiety inventory - state subscale; STAI-T: state-trait anxiety inventory - trait subscale; PWB: physical well-being; SWB: social/family well-being; EWB: emotional well-being; FWB: functional well-being; BCS: breast cancer subscale.

Our results reassure the need of early assessment of cognitive functioning, mood and QOL in order to implement intervention if needed (41). If on the basis of initial cognitive deficit and QOL characteristics risk individuals could be identified, this would imply special intervention for the prevention of later depression or anxiety during the followup care of BC survivors $(41,42)$.

Several methodological biases may compromise the outcome of studies on the neuropsychological effects of ET. Although in our study none of the patients received chemotherapy, still, the type of ET and the age and menopausal status varied. The control group consisted of BC patients with no adjuvant systemic therapy, hence participants constituted quite homogeneous groups. Some studies included control groups of healthy individuals (5, $13,14,15,24)$. BC patients non-treated with ET $(5,12,14$, $15,17,40)$ or both of healthy controls and untreated BC patients $(5,14,15)$. The study of healthy controls may compensate for physiological timely decline of cognitive functioning. We, instead, compensated for that by the statistical methods used. On the other hand, our goal was to consider the effects of ET in BC patients since this has been the relevant issue in our everyday practice. Another issue is study retention, i.e. the proportion and composition of cases having dropped out $(11,17)$. Attrition may result in the selection of data and miss the most vulnerable cases; this phenomenon is more relevant in studies with long follow-up. Actually, we experienced a significant drop out rate of $38.7 \%$ due to different reasons. A strength of the study was the longitudinal design and relatively long observation time. The limitation of the study, however, was the small sample size.

The applied neuropsychological tests are not always appropriate to sensitively detect mild impairments. One of our aims was to specify appropriate methods for further studies on BC patients. The CANTAB test simultaneously detecting a wide range of ability measures is well-established, accurate, easy to handle, and applicable across age, race and culture. These features made it an appropriate instrument for the study of cancer therapy-induced neurotoxicity and cognitive impairment on the domains of learning and memory, executive functions and attention (13). To our best knowledge, the ADAS-Cog test (that we easily had access to) had not been utilized in breast cancer patients; our experience does not suggest its usefulness in this patient population. The MMSE test has been used in breast cancer studies to measure dementia (43, 44), global cognitive functioning (19), or chemotherapy- and radiotherapy-related cognitive deterioration $(45,46)$. The CDT is a commonly used tool for detecting cognitive deficiency also in cancer patients (47-50). The depression and anxiety tests, like BDI $(12,13,17,40)$, HDRS (51), STAI-S and STAI-T $(6,17,24,40)$ have been extensively utilized in breast cancer patients. Vardy, Rourke and Tannock (52) urged for standardization of the methods used for the investigation of chemotherapy-related cognitive changes, and recommended a list of brief and comprehensive 
in vivo 33: 1381-1392 (2019)

Table IV. Contemporary studies, reviews or metaanalyses on the neuropsychological effects of systemic therapies in breast cancer patients.

\begin{tabular}{|c|c|c|c|c|c|c|c|}
\hline Author & $\begin{array}{l}\mathrm{N}, \\
\text { timing }\end{array}$ & $\begin{array}{l}\text { Control } \\
\text { group }\end{array}$ & $\begin{array}{l}\text { Systemic } \\
\text { therapy }\end{array}$ & Endpoints & Methods & Batteries & Outcome \\
\hline $\begin{array}{l}\text { Ganz } 2014 \\
\text { Mind } \\
\text { Body } \\
\text { Study }\end{array}$ & $\begin{array}{c}173, \\
\text { longitudinal } \\
6 \text { and } \\
12 \text { months }\end{array}$ & $\begin{array}{l}\text { No ET } \\
\text { BC }\end{array}$ & $\begin{array}{l}\text { Previous chemo } \\
\quad(\mathrm{N}=90) \\
\text { no previous } \\
\text { chemo }(\mathrm{N}=83) \\
\text { Tam }(\mathrm{N}=61), \\
\text { AI }(\mathrm{n}=57) \text { and } \\
\text { OFS }(\mathrm{N}=4) v s . \\
\text { no ET }(\mathrm{N}=51)\end{array}$ & $\begin{array}{l}\text { Language, } \\
\text { communication, } \\
\text { cognitive, } \\
\text { neuro- } \\
\text { psychological } \\
\text { functioning }\end{array}$ & $\begin{array}{l} \\
\text { Self-administered } \\
\text { questionnaire } \\
\text { Self-reported cognitive } \\
\text { functioning } \\
\text { complaint }\end{array}$ & $\begin{array}{c}\text { IQ (1) } \\
\text { Verbal learning (3) } \\
\text { Verbal memory (4) } \\
\text { Visual learning } \\
\text { and memory }(12) \\
\text { Visuospatial function } \\
(10,15) \\
\text { Psychomotor speed } \\
(15,19,20) \\
\text { Executive function }(15,22) \\
\text { Motor speed }(16) \\
\text { Depressive } \\
\text { symptoms }(31) \\
\text { Self-reported } \\
\text { questionnaire for } \\
\text { cognitive functions }(43)\end{array}$ & $\begin{array}{c}\text { ET worsens } \\
\text { language } \\
\text { communication } \\
\text { and diminishes } \\
\text { neuropsychological } \\
\text { improvement }\end{array}$ \\
\hline $\begin{array}{l}\text { Bender } \\
2015\end{array}$ & $\begin{array}{c}397, \\
\text { longitudinal } \\
0,6,12, \\
18 \text { months }\end{array}$ & Non-BC & $\begin{array}{c}\text { Chemo+ } \\
\text { anastrozole } \\
(\mathrm{N}=114) \text { and } \\
\text { Anastrozole } \\
(\mathrm{N}=173) \text { vs. } \\
\text { no ET }(\mathrm{N}=110)\end{array}$ & $\begin{array}{l}\text { Attention, } \\
\text { learning, memory, } \\
\text { executive functions, } \\
\text { mental flexibiity, } \\
\text { psychomotor } \\
\text { efficiency, } \\
\text { visuospatial ability }\end{array}$ & $\begin{array}{c}\text { Objective } \\
\text { neuropsychological } \\
\text { testing }\end{array}$ & $\begin{array}{c}\text { Verbal intelligence }(2) \\
\text { Attention }(8,26) \\
\text { Learning and memory } \\
(5,8,9,10) \\
\text { Executive function }(8,23) \\
\text { Mental flexibility }(19,23) \\
\text { Psychomotor efficiency } \\
(16,21) \\
\text { Visuospatial ability (10) } \\
\text { Depressive symptoms (31) } \\
\text { Anxiety (34) } \\
\text { Fatigue (34) }\end{array}$ & $\begin{array}{l}\text { Poorer } \\
\text { execution } \\
\text { function } \\
\text { during ET }\end{array}$ \\
\hline $\begin{array}{l}\text { Le Rhun } \\
2015\end{array}$ & $\begin{array}{c}74 \mathrm{ET}, 0,6 \\
12 \text { months }\end{array}$ & - & $\begin{array}{l}\text { AI }(\mathrm{N}=37) v s . \\
\text { Tam }(\mathrm{N}=37)\end{array}$ & $\begin{array}{l}\text { Cognitive global } \\
\text { Verbal episodic } \\
\text { memory } \\
\text { Visual episodic } \\
\text { memory } \\
\text { Working memory } \\
\text { Psychomotor speed } \\
\text { Executive functions }\end{array}$ & $\begin{array}{l}\text { Self-reported } \\
\text { cognitive } \\
\text { functioning complaint }\end{array}$ & $\begin{array}{c}\text { IQ (2) } \\
\text { Global cognitive } \\
\text { functioning (29) } \\
\text { Verbal episodic } \\
\text { memory (5) } \\
\text { Visual episodic } \\
\text { memory }(14) \\
\text { Working memory }(4,13) \\
\text { Processing speed }(19,20) \\
\text { Executive function } \\
(19,20,24,25) \\
\text { Self-reported } \\
\text { questionnaire for } \\
\text { cognitive functions (44) }\end{array}$ & Negative \\
\hline $\begin{array}{l}\text { Phillips } \\
2016 \\
\text { Co-SOFT }\end{array}$ & $\begin{array}{l}74, \\
\text { longitudinal } \\
12 \text { months, } \\
\text { randomized } \\
\text { study }\end{array}$ & - & $\begin{array}{c}\text { Previous } \\
\text { chemo }(\mathrm{N}=21) \\
\text { Tam+OFS }(\mathrm{N}=28) \\
\text { and } \mathrm{AI}+\mathrm{OFS} \\
(\mathrm{N}=26) v s . \\
\text { Tam }(\mathrm{N}=25)\end{array}$ & $\begin{array}{l}\text { Cognitive, } \\
\text { Psychological } \\
\text { distress, } \\
\text { fatigue, } \\
\text { insomnia, } \\
\text { QOL }\end{array}$ & $\begin{array}{c}\text { Objective } \\
\text { neuropsychological } \\
\text { testing } \\
\text { Self-administered } \\
\text { questionnaires } \\
\text { Self-reported } \\
\text { cognitive functioning } \\
\text { complaint }\end{array}$ & $\begin{array}{c}\text { Global cognitive } \\
\text { functioning (30) } \\
\text { Psychological distress (36) } \\
\text { Fatigue (37) } \\
\text { QOL (47) } \\
\text { Self-reported } \\
\text { questionnaire for } \\
\text { cognitive functions (45) }\end{array}$ & $\begin{array}{l}\text { OFS deteriorated } \\
\text { verbal learning } \\
\text { memory as } \\
\text { compared } \\
\text { to Tam alone }\end{array}$ \\
\hline $\begin{array}{l}\text { Van Dyk } \\
2018 \\
\text { Mind } \\
\text { Body } \\
\text { Study }\end{array}$ & $\begin{array}{c}189, \\
\text { cross-sectional }\end{array}$ & - & $\begin{array}{c}\text { previous } \\
\text { chemo }(\mathrm{N}=24) \\
\text { ET }(\mathrm{N}=126) \\
\text { no } \mathrm{ET}(\mathrm{N}=63)\end{array}$ & $\begin{array}{l}\text { Learning, memory, } \\
\text { attention, } \\
\text { visuospatial, } \\
\text { executive function, } \\
\text { processing speed } \\
\text { fatigue, pain, sleep }\end{array}$ & $\begin{array}{c}\text { Objective } \\
\text { neuropsychological } \\
\text { testing }\end{array}$ & $\begin{array}{c}\text { IQ }(1) \\
\text { Learning }(3,4,12) \\
\text { Memory }(3,4,10,12) \\
\text { Attention }(15,19,27) \\
\text { Visuospatial functioning } \\
(10,15) \\
\text { Executive function } \\
(19,20,24)\end{array}$ & $\begin{array}{l}\text { No difference } \\
\text { between groups, but } \\
\text { fatigue, pain, sleep } \\
\text { correlates with } \\
\text { cognitive } \\
\text { functioning }\end{array}$ \\
\hline
\end{tabular}


Table IV. Continued

\begin{tabular}{|c|c|c|c|c|c|c|c|}
\hline Author & $\begin{array}{l}\mathrm{N}, \\
\text { timing }\end{array}$ & $\begin{array}{l}\text { Control } \\
\text { group }\end{array}$ & $\begin{array}{l}\text { Systemic } \\
\text { therapy }\end{array}$ & Endpoints & Methods & Batteries & Outcome \\
\hline & & & & & $\begin{array}{l}\text { Self-administered } \\
\text { questionnaires }\end{array}$ & $\begin{array}{c}\text { Processing speed } \\
(16,20) \\
\text { Sleep quality (39) } \\
\text { Fatigue (38) } \\
\text { BC Symptom checklist (41) } \\
\text { Depressive symptoms (31) } \\
\text { Anxiety (35) }\end{array}$ & \\
\hline $\begin{array}{l}\text { Gregoro- } \\
\text { witsch } \\
2019 \\
\text { UMBRELLA }\end{array}$ & $\begin{array}{l}715, \\
\text { longitudinal, } \\
0,3,6, \\
12,18, \\
24 \text { months }\end{array}$ & & $\begin{array}{l}\text { chemo }(\mathrm{N}=109) \\
\text { and chemo+ET } \\
(\mathrm{N}=252) v s \text {. } \\
\text { no chemo, no ET } \\
(\mathrm{N}=218) \text { and } \\
\text { no chemo, ET } \\
\text { yes }(\mathrm{N}=135)\end{array}$ & $\begin{array}{l}\text { Cognitive, } \\
\text { anxiety, } \\
\text { depression, } \\
\text { QOL, }\end{array}$ & $\begin{array}{c}\text { Self-administered } \\
\text { questionnaires } \\
\text { Self-reported cognitive } \\
\text { functioning complaint }\end{array}$ & $\begin{array}{l}\text { Depression and anxiety (34) } \\
\text { QOL cognitive function (40) } \\
\text { Self-reported } \\
\text { questionnaire } \\
\text { for cognitive } \\
\text { functions (48) }\end{array}$ & $\begin{array}{l}\text { Chemo worsens } \\
\text { self-reported } \\
\text { cognitive } \\
\text { functioning with } \\
\text { the most effect } \\
\text { in pts }<55 \mathrm{yrs}\end{array}$ \\
\hline $\begin{array}{l}\text { Van Dyk } \\
2019 \\
\text { Mind } \\
\text { Body } \\
\text { Study }\end{array}$ & $\begin{array}{l}189, \\
\text { longitudinal } \\
0,6,12 \\
\text { months, } \\
3-6 \text { yrs }\end{array}$ & $\begin{array}{l}\text { No ET } \\
\text { BC }\end{array}$ & $\begin{array}{c}\text { previous } \\
\text { chemo }(\mathrm{N}=24) \\
\text { ET }(\mathrm{N}=126) \\
\text { no } \mathrm{ET}(\mathrm{N}=63)\end{array}$ & $\begin{array}{l}\text { Learning, memory, } \\
\text { attention, } \\
\text { visuospatial, } \\
\text { execution } \\
\text { functioning, } \\
\text { processing speed }\end{array}$ & $\begin{array}{c}\text { Self-administered } \\
\text { questionnaires }\end{array}$ & $\begin{array}{c}\text { IQ }(1) \\
\text { Learning }(3,4,12) \\
\text { Memory }(3,4,10,12) \\
\text { Attention }(15,19,27) \\
\text { Visuospatial } \\
\text { functioning }(10,15) \\
\text { Executive functioning } \\
(19,20,24) \\
\text { Processing speed }(16,20) \\
\text { Anxiety (35) } \\
\text { Depression (31) }\end{array}$ & Negative \\
\hline $\begin{array}{l}\text { Tometich } \\
2019\end{array}$ & $\begin{array}{c}319 \mathrm{BC}+ \\
347 \text { control } \\
\text { ( } \geq 60 \text { yrs }) \\
\text { longitudinal } \\
12,24 \text { months }\end{array}$ & $\begin{array}{l}\text { Non- } \\
\text { cancer } \\
\text { pts }\end{array}$ & $\begin{array}{c}\mathrm{ET}(\mathrm{N}=90) \\
\text { chemo } \pm \mathrm{ET} \\
(\mathrm{N}=217)\end{array}$ & $\begin{array}{l}\text { Depression, anxiety, } \\
\text { fatigue, sleep } \\
\text { disturbancy, } \\
\text { cognition, pain }\end{array}$ & $\begin{array}{c}\text { Objective } \\
\text { neuropsychological } \\
\text { testing } \\
\text { Self-administered } \\
\text { questionnaires } \\
\text { Self-reported cognitive } \\
\text { functioning complaint }\end{array}$ & $\begin{array}{c}\text { Attention, processing } \\
\text { speed and executive } \\
\text { function }(11,15,19,28) \\
\text { Learning and memory }(4,11) \\
\text { QOL (49) } \\
\text { Depressive symptoms }(33) \\
\text { Anxiety (35) } \\
\text { Self-reported } \\
\text { questionnaire for } \\
\text { cognitive functions (46) }\end{array}$ & $\begin{array}{l}\text { Psychoneurological } \\
\text { symptoms predict } \\
\text { lower cognitive } \\
\text { functioning at } \\
\text { baseline and } \\
\text { later on }\end{array}$ \\
\hline $\begin{array}{l}\text { Lee } \\
2016, \\
\text { review }\end{array}$ & $\begin{array}{c}2398(21 \\
\text { studies, } 10 \leq 24 \\
\text { months } \\
11>24 \\
\text { months })\end{array}$ & $\begin{array}{l}\text { Surgery } \\
\text { only } \\
\text { BC } \\
\text { and } \\
\text { healthy }\end{array}$ & & & & & $\begin{array}{l}\text { ET is associated } \\
\text { with impaired } \\
\text { cognitive } \\
\text { functioning }\end{array}$ \\
\hline $\begin{array}{l}\text { Bakoyiannis } \\
2016, \\
\text { meta- } \\
\text { analysis }\end{array}$ & $\begin{array}{l}2381 \\
\text { ET }+ \\
375 \text { control, } \\
\text { longitudinal } \\
\text { 3-24 months }\end{array}$ & $\begin{array}{l}\text { No ET } \\
\text { BC/ } \\
\text { healthy }\end{array}$ & & & & & $\begin{array}{c}\text { Verbal memory } \downarrow \text { in } \\
4 / 5 \text { studies } \\
\text { verbal fluency } \downarrow \text { i } \\
\text { n } 2 / 6 \text { studies } \\
\text { attention, working } \\
\text { memory } \downarrow \text { in } \\
3 / 11 \text { studies } \\
\text { working speed } \downarrow \\
\text { in } 1 / 6 \text { studies }\end{array}$ \\
\hline $\begin{array}{l}\text { Underwood } \\
2018 \text {, } \\
\text { meta- } \\
\text { analysis }\end{array}$ & $\begin{array}{c}911 \mathrm{ET}+ \\
249 \mathrm{BC} \quad \mathrm{B} \\
+662 \\
\text { healthy, } \\
\text { cross-sectional/ } \\
\text { longitudinal } \\
\text { (5-28 months) }\end{array}$ & $\begin{array}{l}\text { No ET } \\
\text { BC/healthy }\end{array}$ & $\begin{array}{l}\text { (previous } \\
\text { chemo: } \\
\text { some } \\
\text { pts) } \\
\text { ET vs. no ET } \\
\text { AI vs. Tam } \\
\text { NSAI vs. SAI }\end{array}$ & $\begin{array}{l}\text { Verbal learning/ } \\
\text { memory } \downarrow \\
\text { visual learning/ } \\
\text { execution/speed } \\
\text { psychomotor } \\
\text { efficiency } \\
\text { visuospatial } \\
\text { function }\end{array}$ & & & $\begin{array}{l}\text { ET pts perform } \\
\text { worse in verbal } \\
\text { learning/memory; } \\
\text { all functions favor } \\
\text { tamoxifen }\end{array}$ \\
\hline
\end{tabular}

AI: Aromatase inhibitor; BC: breast cancer; co: control, chemo: chemotherapy; ET: endocrine therapy; NSAI: non-steroid AI; OFS: ovarian function suppression; pts: patients; RT: radiotherapy; SAI: steroid AI; Tam: tamoxifen; yrs: year. 
tests suitable for serial repetition in a longitudinal study (52). Indeed, we have realized that our methods were not optimal for examining the specific domains of cognitive functioning separately. Another problem is that lengthy testing may be straining to many patients. Actually, in our study, only two of the lost to follow-up patients confessed that neuropsychological tests were too burdensome for them.

Several approaches exist to improve objective evaluation of neuropsychological functioning. The use of circulating or imaging biomarkers could serve to prevent and personalize disease management (53). Correlations have been shown between cognitive functioning and circulating factors such as genetic and inflammatory markers, cerebral spinal fluid constituents, and genetic polymorphisms including ApoE and COMT-Val before and during the treatment of cancer patients $(17,24,53,54)$. In the Mind Body Study, telomerase activity, telomere length, DNA damage comet assay, soluble TNF receptor-II were investigated (54). Higher DNA damage score was related to lower executive function and memory scores; decline in telomerase activity was associated with lower attention, executive function and standardized motor speed. The inflammation marker soluble TNF receptor-II was elevated and related to cognitive difficulties early after chemotherapy, but this association was absent 3-6 years after the therapy (54).

Another approach is the use of novel functional studies such as the quantitative EEG (qEEG) and fMRI study for the objective evaluation of cognitive functioning $(55,56)$. fMRI study was performed on BC patients receiving chemotherapy, $\mathrm{BC}$ patients without such treatment and healthy controls, employing two task paradigms to evaluate therapy-related differences. Task performance did not differ between groups, and did not change over time. Nevertheless, the breast cancer patients who received systemic treatment, showed increased parietal activation compared to baseline indicating increasing executive functioning task load as compared to the two types of controls. This hyperactivation was associated with worse physical functioning, fatigue and more cognitive complaints, but recovery appeared over time (56). Within the Mind Body Study, BC patients were examined by both neuropsychological testing and qEEG. qEEG measures were associated with neuropsychological performance and mood (55).

In conclusion, our study indicates no cognitive impairment during two years of ET. An important finding has been that baseline cognitive scores and QOL dimensions are good predictors of later anxiety and depression. Our results stress the need of refined knowledge about the differential effects of ET on cognition, anxiety, depression and QOL characteristics.

\section{Conflicts of Interest}

The Authors declare that they have no conflict of interest regarding this study.

\section{Authors' Contributions}

Edit Biró - data collection, statistical analysis and interpretation of data, drafting the article; Zsuzsanna Kahán - research conductor, conception and design, analysis and interpretation of data, drafting the article; János Kálmán - research conductor, conception and design, analysis and interpretation of data, drafting the article; Orsolya Rusz - analysis and interpretation of data, revising the article critically for important intellectual content; Magdolna Pákáski - conception and design, revising the article critically for important intellectual content; Tamás Irinyi - data collection, analysis and interpretation of data, revising the article critically for important intellectual content; Gyöngyi Kelemen - conception and design, revising the article critically for important intellectual content; Rita Dudás - conception and design, revising the article critically for important intellectual content; Gergely Drótos statistical analysis and interpretation of data, revising the article critically for important intellectual content; Csaba Hamvai conception and design, data collection, statistical analysis and interpretation of data, drafting the article, revising the article critically for important intellectual content.

\section{References}

1 Bray F, Ferlay J, Soerjomataram I, Siegel R L, Torre L A and Jemal A: Global cancer statistics 2018: GLOBOCAN estimates of incidence and mortality worldwide for 36 cancers in 185 countries. CA-Cancer J Clin 68(6): 394-424, 2018. PMID: 30207593. DOI: $10.3322 /$ caac. 21492

2 Morin RT and Midlarsky E: Treatment with chemotherapy and cognitive functioning in older adult cancer survivors. Arch Phys Med Rehab 99(2): 257-263, 2018. PMID: 28735719. DOI: 10.1016/j.apmr.2017.06.016

3 Gregorowitsch ML, Ghedri A, Young-Afat DA, Bijlsma R, Baas IO, van Schaik-van de Mheen C, Agterof MJ, Göker E, Hinink DB, van den Bongard HJGD and Verkooijen HM; UMBRELLA study group: The effect of chemotherapy on subjective cognitive function in younger early-stage breast cancer survivors treated with chemotherapy compared to older patients. Breast Cancer Res Treat 175: 429-441, 2019. PMID: 30746636. DOI: 10.1007/ s10549-019-05149-4

4 Blaustein JD: (2017). Treatments for breast cancer that affect cognitive function in postmenopausal women. Policy Insights Behav Brain Sci 4(2): 170-177, 2017. DOI: 10.1177/ 23727322 17717271

5 Bakoyiannis I, Tsigka E A, Perrea D and Pergialiotis V: The impact of endocrine therapy on cognitive functions of breast cancer patients: a systematic review. Clin drug invest 36(2): 109118, 2016. PMID: 26619839. DOI: 10.1007/s40261-015-0364-9

6 Von Ah D and Tallman EF: Perceived cognitive function in breast cancer survivors: evaluating relationships with objective cognitive performance and other symptoms using the functional assessment of cancer therapy - cognitive function instrument. J Pain Symptom Manag 49(4): 697-706, 2015. PMID: 25240787. DOI: $10.1016 /$ j.jpainsymman.2014.08.012

7 Xu S, Thompson W, Ancoli-Israel S, Liu L, Palmer B and Natarajan L: Cognition, quality-of-life, and symptom clusters in breast cancer: Using Bayesian networks to elucidate complex relationships. Psycho-oncol 27(3): 802-809, 2018. PMID: 29055062. DOI: $10.1002 /$ pon. 4571 
8 Hopwood P, Haviland J, Mills J, Sumo G and Bliss JM: The impact of age and clinical factors on quality of life in early breast cancer: an analysis of 2208 women recruited to the UK START Trial (Standardisation of Breast Radiotherapy Trial). The Breast 16(3): 241-251, 2007. PMID: 17236771. DOI: 10.1016/ j.breast.2006.11.003

9 Janelsins MC, Heckler CE, Peppone LJ, Kamen C, Mustian KM, Mohile SG and Conlin AK: Cognitive complaints in survivors of breast cancer after chemotherapy compared with age-matched controls: an analysis from a nationwide, multicenter, prospective longitudinal study. J Clin Oncol 35(5): 506, 2017. PMID: 28029304. DOI: $10.1200 / \mathrm{JCO} .2016 .68 .5826$

10 Klemp JR, Myers JS, Fabian CJ, Kimler BF, Khan QJ, Sereika SM and Stanton AL: Cognitive functioning and quality of life following chemotherapy in pre-and peri-menopausal women with breast cancer. Support Care Cancer 26(2): 575-583, 2018 DOI: 10.1007/s00520-017-3869-3

11 Yao C, Bernstein LJ and Rich JB: Executive functioning impairment in women treated with chemotherapy for breast cancer: a systematic review. Breast Cancer Res Treat 166(1): 1528, 2017. PMID: 28707202. DOI: 10.1007/s10549-017-4376-4

12 Ganz PA, Petersen L, Castellon SA, Bower JE, Silverman DH, Cole SW, Irwin MR and Belin TR: Cognitive function after the initiation of adjuvant endocrine therapy in early-stage breast cancer: an observational cohort study. J Clin Oncol 32(31): 3559-3567, 2014. PMID: 25267747. DOI: 10.1200/JCO. 2014 56.1662

13 Bender CM, Merriman JD, Gentry AL, Ahrendt GM, Berga SL, Brufsky AM, Casillo FE, Dailey MM, Erickson KI, Kratofil FM, Priscilla F, McAuliffe PF, Rosenzweig MQ, Ryan CM and Sereika SM: Patterns of change in cognitive function with anastrozole therapy. Cancer 121(15): 2627-2636, 2015. PMID: 25906766. DOI: $10.1002 /$ cncr.29393

14 Lee PE, Tierney MC, Wu W, Pritchard KI and Rochon PA: Endocrine treatment-associated cognitive impairment in breast cancer survivors: evidence from published studies. Breast Cancer Res Treat 158(3): 407-420, 2016. PMID: 27432418. DOI: $10.1007 / \mathrm{s} 10549-016-3906-9$

15 Underwood EA, Rochon PA, Moineddin R, Lee PE, Wu W, Pritchard KI and Tierney MC: Cognitive sequelae of endocrine therapy in women treated for breast cancer: a meta-analysis. Breast Cancer Res Treat 168(2): 299-310, 2018. PMID: 29264751. DOI: $10.1007 / \mathrm{s} 10549-017-4627-4$

16 Underwood EA, Jerzak KJ, Lebovic G, Rochon PA, Elser C, Pritchard KI and Tierney MC: Cognitive effects of adjuvant endocrine therapy in older women treated for early-stage breast cancer: a 1-year longitudinal study. Support Care Cancer 1-9, 2019. PMID: 30610433. DOI: 10.1007/s00520-018-4603-5

17 Van Dyk K, Crespi CM, Bower JE, Castellon SA, Petersen L and Ganz PA: The cognitive effects of endocrine therapy in survivors of breast cancer: A prospective longitudinal study up to 6 years after treatment. Cancer 125(5): 681-689, 2019. PMID: 3048 5399. DOI: $10.1002 / \mathrm{cncr} .31858$

18 Phillips KA, Regan MM, Ribi K, Francis PA, Puglisi F, Bellet M, Spazzapan S, Karlsson P, Duman DR, Zaman K, Abdi EA, Domchek SM, Feng Y, Price KN, Coates AS, Gelber RD, Maruff P, Boyle F, Forbes JF, Ahles T, Fleming GF and Bernhard J: Adjuvant ovarian function suppression and cognitive function in women with breast cancer. Brit J Cancer 114(9): 956, 2016. PMID: 27092785. DOI: 10.1038/bjc.2016.71
19 Le Rhun E, Delbeuck X, Lefeuvre-Plesse C, Kramar A, Skrobala E, Pasquier F and Bonneterre J: A phase III randomized multicenter trial evaluating cognition in post-menopausal breast cancer patients receiving adjuvant hormonotherapy. Breast Cancer Res Treat 152(3): 569-580, 2015. PMID: 26160250. DOI: $10.1007 / \mathrm{s} 10549-015-3493-1$

20 Rossetti MF, Cambiasso MJ, Holschbach MA and Cabrera R: Oestrogens and progestagens: synthesis and action in the brain. J Neuroendocrinol 28(7): 2016. PMID: 27306650. DOI: 10.1111/ jne. 12402

21 Catenaccio E, Mu W and Lipton ML: Estrogen-and progesteronemediated structural neuroplasticity in women: evidence from neuroimaging. Brain Struct Funct 221(8): 3845-3867, 2016. PMID: 26897178. DOI: 10.1007/s00429-016-1197-x

22 Korol DL and Pisani SL: Estrogens and cognition: Friends or foes?: An evaluation of the opposing effects of estrogens on learning and memory. Horm Behav 74: 105-115, 2015. PMID: 26149525. DOI: 10.1016/j.yhbeh.2015.06.017

23 Hurria A, Patel SK, Mortimer J, Luu T, Somlo G, Katheria V, Ramani R, Hansen K, Feng T, Chuang C, Geist CL and Silverman DHS: The effect of aromatase inhibition on the cognitive function of older patients with breast cancer. Clin Breast Cancer 14(2): 132-140, 2014. PMID: 24291380. DOI: $10.1016 / \mathrm{j} . \mathrm{clbc} .2013 .10 .010$

24 Tometich DB, Small BJ, Carroll JE, Zhai W, Luta G, Zhou X, Kobayashi LC, Ahles T, Saykin AJ, Clapp JD, Jim HSL, Jacobsen PB, Hurria, A, Graham D, McDonald B, Denduluri N, Extermann M, Isaacs C, Dilawari A, Root J, Rini C and Mandelblatt JS: Pretreatment psychoneurological symptoms and their association with longitudinal cognitive function and quality of life in older breast cancer survivors. J Pain Symptom Manag 57(3): 596-606, 2019. PMID: 30472317. DOI: 10.1016/ j.jpainsymman.2018.11.015

25 Vergani L, Marton G, Pizzoli SFM, Monzani D, Mazzocco K and Pravettoni G: Training cognitive functions using mobile apps in breast cancer patients: systematic review. JMIR mHealth and uHealth 7(3): e10855, 2019. PMID: 30888326. DOI: 10.2196/10855

26 Bedillion MF, Ansell EB and Thomas GA: Cancer treatment effects on cognition and depression: The moderating role of physical activity. The Breast 44: 73-80, 2019.

27 Rosen WG, Mohs RC and Davis KL: A new rating scale for Alzheimer's disease. The Am J Psychiat 141(11): 1356-1364, 1984. PMID: 30685529. DOI: 10.1016/j.breast.2019.01.004

28 Pákáski M, Drótos G, Janka Z and Kálmán J: Validation of the Hungarian version of Alzheimer's Disease Assessment Scalecognitive subscale. Orv Hetil 153(12): 461-466, 2012. PMID: 22411219. DOI: $10.1556 / \mathrm{OH} .2012 .29332$

29 Fray PJ, Robbins TW and Sahakian BJ: Neuorpsychiatyric applications of CANTAB. Int J Geriatr Psych 11(4): 329-336, 1996. DOI: 10.1002/(SICI)1099-1166(199604)11:4<329::AIDGPS453>3.0.CO;2-6

30 Critchley M: The parietal lobes. Oxford, England, 1953.

31 Kálmán J, Maglóczky E and Janka Z: Óra Rajzolási Teszt: Gyors és egyszerú demencia szúrőmódszer. Psychiatria Hungarica: A Magyar Pszichiátriai Társaság tudományos folyóirata 10: 11-18, 1995.

32 Folstein MF, Folstein SE and McHugh PR: "Mini-mental state": a practical method for grading the cognitive state of patients for the clinician. J Psychiat Res 12(3): 189-198, 1975. PMID: 1202204 
33 Janka Z, Somogyi A, Maglóczky E, Paláski M and Kálmán J: Dementia screening study by a short cognitive test. Orv Hetil 129: 2797-2800 (in Hungarian), 1988.

34 Beck A T, Ward C and Mendelson M: Beck depression inventory (BDI). Arch Gen Psychiatry 4(6): 561-571, 1961.

35 Hamilton M: A rating scale for depression. J Neurol Neurosur Ps 23(1): 56, 1960 .

36 Tringer L: A Hamilton-féle depresszió skála alkalmazása. Ideggyógyászati szemle 23: 11-16, 1970.

37 Spielberger CD, Gorsuch RL and Lushene RE: STAI. Manual for the State-Trait Anxiety Inventory (Self Evaluation Questionnaire). Palo Alto California: Consulting Psychologist, 1970.

38 Sipos K and Sipos M: The development and validation of the Hungarian Form of the State-Trait Anxiety Inventory. Ser Clin C 2: 27-39, 1983.

39 Brady MJ, Cella DF, Mo F, Bonomi AE, Tulsky DS, Lloyd SR, Deasy S, Cobleigh M and Shiomoto G: Reliability and validity of the Functional Assessment of Cancer Therapy-Breast qualityof-life instrument. J Clin Oncol 15(3): 974-986, 1997. PMID: 9060536. DOI: 10.1200/JCO.1997.15.3.974

40 Van Dyk K, Bower JE, Crespi CM, Petersen L and Ganz PA: Cognitive function following breast cancer treatment and associations with concurrent symptoms. NPJ Breast Cancer 4(1): 25, 2018. PMID: 30131974. DOI: 10.1038/s41523-018-0076-4

41 Asher A, Van Dyk K, Patel S K, Newman R, Engle J, Hutchison $\mathrm{N}$ and Padgett L: Cancer-related cognitive changes. Arch Phys Med Rehab 98(12): 2595-2596, 2017. PMID: 28916183. DOI: 10.1016/j.apmr.2017.05.011

42 Runowicz CD, Leach CR, Henry NL, Henry KS, Mackey HT, Cowens-Alvarado RL, Cannady RS, Pratt-Chapman ML, Edge SB, Jacobs LA, Hurria A, Marks LB, LaMonte SJ, Warner E, Lyman GH and Ganz PA: American Cancer Society/American Society of Clinical Oncology Breast Cancer Survivorship Care Guideline. CA Cancer J Clin 66(1): 43-73, 2016. PMID: 26641959. DOI: $10.3322 /$ caac.21319

43 Eberling JL, Wu C, Tong-Turnbeaugh $\mathrm{R}$ and Jagust WJ: Estrogen-and tamoxifen-associated effects on brain structure and function. Neuroimage 21(1): 364-371, 2004. PMID: 14741674.

44 Lejbak L, Vrbancic M and Crossley M: Endocrine therapy is associated with low performance on some estrogen-sensitive cognitive tasks in postmenopausal women with breast cancer. $\mathrm{J}$ Clin Exp Neuropsychol 32(8): 836-846, 2010. PMID: 20336566. DOI: $10.1080 / 13803391003596389$

45 Guida M, Barulli MR, Stangalino C, Mariani L, Caraceni A, Lepore V, Livrea P, De Caro MF, Gallus G and Lorusso V: Impairment of cognitive function in patients submitted to adjuvant chemotherapy for early breast cancer: A follow up study. In ASCO Annual Meeting Proceedings 22(14): 8027, 2004. DOI: 10.1200/jco.2004.22.14_suppl.8027

46 Fuller CD, Schillerstrom JE, Jones WE, Boersma M, Royall DR and Fuss M: Prospective evaluation of pretreatment executive cognitive impairment and depression in patients referred for radiotherapy. Int J Radiat Oncol 72(2): 529-533, 2008. PMID: 18411001. DOI: 10.1016/j.ijrobp.2007.12.040
47 Paganini-Hill A and Clark LJ: Preliminary assessment of cognitive function in breast cancer patients treated with tamoxifen. Breast Cancer Res Treat 64(2): 165-176, 2000. PMID: 11194452.

48 Tannock IF, Ahles TA, Ganz PA and van Dam FS: Cognitive impairment associated with chemotherapy for cancer: Report of a Workshop. J Clin Oncol 22: 2233-2239, 2004. PMID: 15169812. DOI: $10.1200 / \mathrm{JCO} .2004 .08 .094$

49 O’Shaughnessy JA, Vukelja SJ, Holmes FA, Savin M, Jones M, Royall D, George M and Von Hoff D: Feasibility of quantifying the effects of epoetin alfa therapy on cognitive function in women with breast cancer undergoing adjuvant or neoadjuvant chemotherapy. Clin Breast Cancer 5(6): 439-446, 2005. PMID: 15748464.

50 Andreis F, Ferri M, Mazzocchi M, Meriggi F, Rizzi A, Rota L, Di Biasi B, Abeni C, Codignola C, Rozzini R and Alberto Z: Lack of a chemobrain effect for adjuvant FOLFOX chemotherapy in colon cancer patients. A pilot study. Support Care Cancer 21: 583-590, 2013. PMID: 22886390. DOI: 10.1007/s00520-012-1560-2

51 Chen X, Li J, Chen J, Li D, Ye R, Zhang J, Zhu C, Tian Y and Wang K: Decision-making impairments in breast cancer patients treated with tamoxifen. Horm Behav 66(2): 449-456, 2014. PMID: 25036869. DOI: 10.1016/j.yhbeh.2014.07.005

52 Vardy J, Rourke S and Tannock IF: Evaluation of cognitive function associated with chemotherapy: a review of published studies and recommendations for future research. J Clin Oncol 25(17): 2455-2463, 2007. PMID: 17485710. DOI: 10.1200/JCO. 2006.08.1604

53 Castel H, Denouel A, Lange M, Tonon MC, Dubois M and Joly F: Biomarkers associated with cognitive impairment in treated cancer patients: potential predisposition and risk factors. Front Pharmacol 8: 138, 2017. PMID: 28377717. DOI: 10.3389/fphar. 2017.00138

54 Carroll JE, Van Dyk K, Bower JE, Scuric Z, Petersen L, Schiestl $R$, Irwin MR and Ganz PA: Cognitive performance in survivors of breast cancer and markers of biological aging. Cancer 125(2): 298-306, 2019. PMID: 30474160. DOI: 10.1002/cncr.31777

55 Van Dyk K, Hunter AM, Ercoli L, Petersen L, Leuchter AF and Ganz PA: Evaluating cognitive complaints in breast cancer survivors with the FACT-Cog and quantitative electroencephalography. Breast Cancer Res Treat 166(1): 157-166, 2017. PMID: 28707203. DOI: 10.1007/s10549-017-4390-6

56 Menning S, De Ruiter MB, Veltman DJ, Boogerd W, Oldenburg HS, Reneman L and Schagen SB: Changes in brain activation in breast cancer patients depend on cognitive domain and treatment type. PloS One 12(3): e0171724, 2017. PMID: 28267750. DOI: 10.1371/journal.pone. 0171724 